Tersedia online di: http://ejournal-balitbang.kkp.go.id/index.php/jra

\title{
EFEKTIVITAS KOMBINASI PROBIOTIK MIKROENKAPSULASI MELALUI PAKAN UNTUK PENGENDALIAN PENYAKIT MOTILE AEROMONADS SEPTICEMIA PADA IKAN LELE, Clarias gariepinus
}

\author{
Angela Mariana Lusiastuti ${ }^{\#}$, Septyan Andriyanto, dan Reza Samsudin \\ *) Balai Riset Perikanan Budidaya Air Tawar dan Penyuluhan Perikanan
}

(Naskah diterima: 25 Juli 2016; Revisi final: 10 Juli 2017; Disetujui publikasi: 11 Juli 2017)

\begin{abstract}
ABSTRAK
Penelitian ini bertujuan untuk mengetahui efektivitas kombinasi probiotik mikroenkapsulasi melalui pakan dalam pengendalian penyakit pada ikan lele, Clarias gariepinus. Penelitian dilakukan mulai dari penyiapan kombinasi probiotik Bacillus cereus ND2 dan Staphylococcus lentus L1K, mikroenkapsulasi probiotik, uji probiotik mikroenkapsulasi, serta uji dosis secara in vivo. Proses mikroenkapsulasi menggunakan BUCHI mini spray dryer dengan suhu inlet $131^{\circ} \mathrm{C}-133^{\circ} \mathrm{C}$ dan suhu outlet $65^{\circ} \mathrm{C}-70^{\circ} \mathrm{C}$. Pakan yang digunakan adalah pakan buatan dengan kadar protein 38\%yang dicampur dengan probiotik mikroenkapsulasi sesuai dengan dosis perlakuan dan diberi putih telur $2 \%$ sebagai binder. Perlakuan yang dilakukan adalah membandingkan secara in vivo probiotik mikroenkapsulasi (PM) dan probiotik non-mikroenkapsulasi (PNM), dan dilanjutkan pengujian dosis melalui pakan untuk memperoleh dosis terbaik dari aplikasi probiotik mikroenkapsulasi. Parameter pengamatan berupa tingkat sintasan, biomassa, kadar hematokrit, hemoglobin, respiratory burst activity, dan total bacterial count. Hasil penelitian menunjukkan bahwa suplementasi kombinasi probiotik mikroenkapsulasi Bacillus cereus ND2 dan Staphylococcus lentus L1K pada pakan lebih efektif, dan dengan dosis $2 \%$ menunjukkan hasil yang lebih baik dalam meningkatkan sintasan hingga $97,33 \%$ biomassa dan respons imun (NBT assay, hematocrit, hemoglobin) ikan lele terhadap A. hydrophila.
\end{abstract}

KATA KUNCl: mikroenkapsulasi; probiotik; pakan; in vivo; ikan lele

ABSTRACT: The effectivity combination of microencapsulated probiotic through diet to control of motile aeromonads septicemia disease in catfish, Clarias gariepinus. By: Angela Mariana Lusiastuti, Septyan Andriyanto, and Reza Samsudin

This study was aimed to know the effectivity of microencapsulated probiotic combinations administered through diet to control motile aeromonads septicemia disease in catfish (Clarias gariepinus). The research stages consisted of preparation probiotics, microencapsulation of probiotics and probiotic microencapsulation testing in vivo. $\mathrm{BUCHI}$ mini spray dryer was used in the microencapsulation process with inlet temperature ranged between $131^{\circ} \mathrm{C}-133^{\circ} \mathrm{C}$ and outlet temperature ranged between $65^{\circ} \mathrm{C}-70^{\circ} \mathrm{C}$. The diets used in the research were pelleted feeds with a protein content of $38 \%$ and mixed with different dosages of microencapsulated probiotics. Egg albumen $(2 \%$ was used to bind the mixture. The effectivity of microencapsulated and non-microencapsulated feeds was compared in order to find an optimum microencapsulation dosage. The observed parameters were survival rate, biomass, hematocrit, hemoglobin, respiratory burst activity, and total bacterial count. The results showed that the supplementation of microencapsulated probiotic Bacillus cereus ND2 and Staphylococcus Ientus L1K in the diets was more effectiveat a dose of 2\% showing better survival rate $(97.33 \%$, biomass gain, and immune responses (NBT assay, hematocrit, hemoglobin) against $\mathbf{A}$. hydrophila in catfish Clarias gariepinus.

KEYWORDS: microencapsulation; probiotic; fed; in vivo; catfish

\# Korespondensi: Balai Riset Perikanan Budidaya Air Tawar dan

Penyuluhan Perikanan. Jl. Sempur No. 1, Bogor 16154,

Indonesia. Tel. + (0251) 8313200

E-mail: Iusiastuti_61@yahoo.co.id 


\section{PENDAHULUAN}

Penggunaan probiotik merupakan salah satu metode pengendali penyakit ikan yang aman dan ramah lingkungan. Penggunaan probiotik dapat mengurangi penggunaan anti-mikroba seperti antibiotik, di mana probiotik bertindak sebagai agen biokontrol yang dapat mengurangi populasi suatu jenis patogen (Cruz et al., 2012). Penggunaan probiotik multispesies diketahui memiliki efektivitas yang lebih tinggi dalam menghambat penyebaran beberapa jenis penyakit bakterial (Thomas \& Chhorn, 2011). Hasibuan (2013) melaporkan bahwa kombinasi bakteri probiotik Bacillus cereus ND2 dan Staphylococcus lentus L1K dalam pakan dapat meningkatkan respons imun dan dapat mengurangi tingkat kematian ikan akibat infeksi Streptococcus agalactiae.

Menurut Iribarren et al. (2012), penggunaan probiotik menjadi solusi untuk menghasilkan pertumbuhan dan efisiensi pakan, mengurangi biaya produksi dan pada akhirnya dapat mengurangi beban lingkungan karena akumulasi limbah di perairan. Probiotik dalam bentuk kultur sel memiliki keterbatasan dalam masa penyimpanan dan mudah rusak oleh pengaruh lingkungan (Weinbreck et al., 2010). Probiotik harus mampu bertahan selama proses metabolisme oleh asam lambung, enzim, dan garam empedu yang terdapat dalam usus. Berdasarkan hal tersebut perlu adanya suatu teknologi yang menghasilkan barier fisik yang memberikan perlindungan pada probiotik untuk menghindari pengaruh kondisi lingkungan yang mengganggu kelangsungan hidup bakteri probiotik. Salah satu metode yang dapat diterapkan adalah mikroenkapsulasi (Jafari et al., 2008).

Teknik mikroenkapsulasi yang banyak digunakan secara komersial antara lain spray drying, air suspension coating, spray cooling, dan spray chilling (extrusion), centrifugal extrusion, rotational suspension separation, inclusion complexing (Victor \& Heldman, 2001). Teknik spray drying merupakan teknik yang sering diterapkan pada bakteri. Mikroenkapsulasi merupakan teknik penyalutan suatu bahan sehingga bahan tersebut dapat dilindungi dari pengaruh lingkungan yang tidak menguntungkan seperti panas dan bahan kimia (Victor \& Heldman, 2001). Mikroenkapsulasi banyak diaplikasikan pada produk pangan untuk memperpanjang waktu penyimpanan probiotik dan viabilitas sel probiotik dalam sebuah beads mikrokapsul (Krasaekoopt et al., 2003), tetapi mikroenkapsulasi probiotik dalam akuakultur masih belum banyak diteliti (Nimrat et al., 2012). Munaeni et al. (2014) menyatakan bahwa pemberian mikrokapsul simbiotik Bacillus sp. NP5 dan oligosakarida dengan frekuensi yang berbeda memberikan pengaruh yang nyata terhadap laju pertumbuhan dan respons imun pada udang vaname yang terinfeksi Vibrio harveyi.

Penelitian ini bertujuan untuk mengetahui efektivitas kombinasi probiotik melalui pakan dalam pengendalian penyakit ikan lele Clarias gariepinus.

\section{BAHAN DAN METODE}

Penelitian ini dilaksanakan di Instalasi Penelitian dan Pengembangan Pengendalian Penyakit Ikan Depok, Balai Penelitian dan Pengembangan Budidaya Air Tawar (BPPBAT) Bogor pada bulan Agustus-Oktober 2015. Ikan lele yang digunakan adalah strain Mutiara dari Balai Penelitian dan Pemuliaan Ikan Sukamandi. Penelitian ini dilakukan mulai dari penyiapan probiotik, mikroenkapsulasi probiotik, dan uji probiotik termikroenkapsulasi secara in vivo.

\section{Penyiapan Bakteri Probiotik}

Bakteri probiotik yang digunakan dalam penelitian ini adalah probiotik dua-spesies yang terdiri atas kombinasi isolat bakteri Bacillus cereus ND2 merupakan koleksi BPPBAT Bogor yang mampu menghambat patogen $A$. hydrophila dan berfungsi sebagai imunostimulan, dan Staphylococcus lentus L1K koleksi dari Fakultas Perikanan dan IImu Kelautan-Institut Pertanian Bogor yang merupakan kombinasi terbaik melalui pakan. Staphylococcus lentus L1K mempunyai kemampuan meningkatkan tingkat kecernaan pakan karena dapat memproduksi enzim saluran cerna yaitu lipase, amilase, dan protease (Sekar et al., 2012).

\section{Mikroenkapsulasi Probiotik}

Bahan penyalut yang digunakan pada mikroenkapsulasi probiotik ini adalah protein whey dan maltodekstrin (1:1). Proses mikroenkapsulasi dilakukan dengan metode spray drying. Metode ini menurut Jackson \& Lee (1991), melibatkan dispersi bahan inti ke dalam larutan polimer, membentuk emulsi atau dispersi, diikuti dengan homogenisasi cairan, kemudian atomisasi campuran ke dalam drying chamber. Kultur probiotik dalam bentuk biomassa diresuspensikan dengan akuades steril dan dimikroenkapsulasi dengan bahan penyalut. Perbandingan biomassa probiotik dan bahan penyalut adalah 1:1 (b/v) (Seveline, 2005). Campuran yang terdiri atas kultur bakteri, bahan penyalut whey dan maltodextrin dihomogenasikan dengan mixer kemudian dimikroenkapsulasi dengan BUCHI mini spray dryer dengan suhu inlet $131^{\circ} \mathrm{C}-133^{\circ} \mathrm{C}$ dan suhu outlet $65^{\circ} \mathrm{C}-70^{\circ} \mathrm{C}$. Probiotik mikroenkapsulasi yang diperoleh selanjutnya dimasukkan ke dalam botol kaca steril dan disimpan pada suhu lemari pendingin $4^{\circ} \mathrm{C}-8^{\circ} \mathrm{C}$. 


\section{Pakan}

Pakan yang digunakan dalam penelitian ini adalah pakan buatan dari Laboratorium Nutrisi Balai Penelitian dan Pengembangan Budidaya Air Tawar, Bogor dengan kadar protein 38\%(Tabel 1). Pencampuran pakan dan probiotik menggunakan putih telur $2 \%$ sebagai binder, setelah itu, dikering-anginkan dan disimpan dalam lemari pendingin bersuhu $4^{\circ} \mathrm{C}$.

\section{Perlakuan dan Pemeliharaan Hewan Uji}

Kegiatan ini ada dua tahap, tahap pertama adalah aplikasi kombinasi probiotik mikroenkapsulasi dan tidak dimikroenkapsulasi. Adapun ikan uji yang digunakan pada penelitian ini adalah ikan lele strain Mutiara sebanyak 30 ekor/akuarium dengan bobot 10$20 \mathrm{~g}$. Akuarium yang digunakan ukuran $60 \mathrm{~cm} \times 70 \mathrm{~cm}$ $x 40 \mathrm{~cm}$ dengan volume air $60 \mathrm{~L}$. Sebelum diterapkan perlakuan, ikan uji diadaptasikan terlebih dahulu selama tujuh hari. Ikan-ikan tersebut diberi perlakuan: pemberian pakan dengan penambahan probiotik mikroenkapsulasi 2\%(PM), pemberian pakan dengan penambahan probiotik tidak dimikroenkapsulasi $2 \%$ (PNM), pelet tanpa probiotik mikroenkapsulasi $(\mathrm{K}+)$ dan pelet tanpa probiotik dan mikroenkapsulasi (K-). Masing-masing perlakuan diulang tiga kali. Pemberian pakan dilakukan sebanyak tiga kali sehari pada pagi (08.00), siang (12.00), dan sore hari (16.00) secara ad satiation selama 40 hari masa pemeliharaan.

Tahap kedua adalah optimasi dosis aplikasi probiotik melalui pakan untuk memperoleh dosis yang tepat. Dalam pengujian dosis perlakuan probiotik dengan K+ dan K-pemberian pakan tanpa penambahan probiotik mikroenkapsulasi. Sementara untuk perlakuan lainnya adalah (A) dosis probiotik mikroenkapsulasi $0,5 \%$ (B) dosis probiotik mikroenkapsulasi $1 \%$ (C) dosis probiotik mikroenkapsulasi 2\% Masing-masing perlakuan diulang tiga kali. Lama pemeliharaan ikan lele untuk uji optimasi dosis probiotik mikroenkapsulasi adalah 14 hari.

\section{Uji Tantang Bakteri}

Uji tantang dilakukan dengan menginfeksikan ikan lele pada perlakuan $\mathrm{K}+, \mathrm{A}, \mathrm{B}, \mathrm{C}$, dengan bakteri $\mathrm{A}$. hydrophila $10^{7} \mathrm{cfu} / \mathrm{mL}$ melalui injeksi secara intraperitoneal, sedangkan K- diinjeksi dengan larutan PBS. Parameter yang diamati pada tahapan penelitian ini adalah hematokrit, hemoglobin, biomassa, dan total bacterial count. Pengamatan sintasan pasca uji tantang dilakukan dengan mengamati kematian setiap hari selama 14 hari.

Ikan lele pada perlakuan PN, PNM, dan $\mathrm{K}+$ hasil pemeliharaan selama 42 hari, selanjutnya diuji tantang dengan bakteri $\mathrm{A}$. hydrophila dengan kepadatan $10^{8}$ cfu $\mathrm{mL}^{-1}$ melalui penyuntikan intraperitoneal sebanyak $0,2 \mathrm{~mL}$ per ekor menggunakan tuberculine syringe steril. Sedangkan ikan lele pada perlakuan K- diinjeksi dengan PBS (phosphate buffer saline) dengan dosis yang sama dengan di atas. Masing-masing 90 ekor ikan per perlakuan (30 ekor per akuarium atau tiga ulangan per perlakuan) dipelihara dan tetap diberi pakan perlakuan selama 14 hari pasca uji tantang.

Parameter yang diamati pada uji in vivo ini adalah sintasan, sistem imun non-spesifik meliputi respiratory burst activity (Nitro Blue Tetrazolium, NBT assay), kadar hematokrit, hemoglobin, dan total bacterial count.

Tabel 1. Komposisi pakan uji

Tablel. The composition of test diets

\begin{tabular}{lc}
\hline \multicolumn{1}{c}{ Bahan pakan (Ingredients) } & Komposisi (Composition) $\mathbf{( g / 1 0 0 ~ g ) ~}$ \\
\hline Tepung ikan (Fish meal) & 17.5 \\
Bungkil kedelai (Soybean meal) & 20 \\
Tepung tulang dan daging (M eat and bone meal) & 15 \\
Tepung udang (Shrimp meal) & 15 \\
Dedak padi (Rice bran) & 10 \\
Dedak pollard (Pollard) & 10 \\
Minyak ikan (Fish oil) & 3 \\
Minyak jagung (Corn oil) & 3 \\
Vitamin (Vitamin premix) & 2 \\
Mineral (Mineral premix) & 1.5 \\
Tapioka (Tapioca) & 3 \\
\hline \multicolumn{2}{c}{ Total } \\
\hline
\end{tabular}




\section{Aktivitas Respiratory Burst}

Uji aktivitas respiratory burst menggunakan reagen Nitro Blue Tetrazolium (NBT) berdasarkan metode Secombes (1990). Darah dari ikan sampel diambil sebanyak $50 \mu \mathrm{L}$ dimasukkan dalam microplate, diinkubasi selama satu jam suhu $37^{\circ} \mathrm{C}$, kemudian supernatan dibuang dan dicuci PBS $50 \mu \mathrm{L}$ diulang sebanyak tiga kali, ditambahkan $50 \mu \mathrm{L} \mathrm{NBT} 0,2 \%$ diinkubasi selama satu jam pada suhu $37^{\circ} \mathrm{C}$. Fiksasi metanol 100\% $(50 \mu \mathrm{L})$ 2-3 menit lalu dibilas dengan metanol 30\% (50 $\mu \mathrm{L})$ tiga kali dan dikering-udarakan, kemudian ditambah KOH $60 \mu \mathrm{L}+$ DMSO $70 \mu \mathrm{L}$ dan kemudian dicek optical density-nya menggunakan ELISA Reader dengan panjang gelombang $540 \mathrm{~nm}$.

\section{Total Bacteria Count}

Perhitungan populasi sel bakteri total dan probiotik dilakukan pada organ target usus. Media yang digunakan adalah TSA untuk menghitung populasi total bakteri dalam usus, TSA + cef $100 \mu \mathrm{g} \mathrm{mL}^{-1}$ untuk menghitung populasi sel probiotik ND2 Cef $^{R}$ dan TSA + Tet $100 \mu \mathrm{g} \mathrm{mL}^{-1}$ untuk menghitung populasi sel probiotik L2k Tet ${ }^{R}$. Perhitungan populasi sel probiotik dihitung dengan cara Total Plate Count (TPC).

\section{Kadar Hematokrit}

Hematokrit merupakan persentase volume eritrosit dalam darah ikan. Kadar hematokrit diukur menurut Anderson \& Siwicki (1995), yaitu dengan menggunakan tabung mikro hematokrit yang berupa pipa kapiler berlapis heparin. Pengukuran dilakukan dengan membandingkan bagian darah yang mengendap (a) dengan seluruh bagian darah yang ada dalam tabung mikrohematokrit (b). Kadar hematokrit dinyatakan sebagai persen (\%) volume padatan sel darah yang dihitung dengan cara: $\mathrm{He}=\mathrm{a} / \mathrm{b} \times 100 \%$

\section{Kadar Hemoglobin}

Kadar hemoglobinn diukur menggunakan metode Sahli dengan Sahlinometer (Wedemeyer \& Yasutake, 1977) dengan cara mengisi tabung sahlinometer dengan larutan $\mathrm{HCl} 0,1 \mathrm{~N}$ sampai angka 10 lalu menempatkan tabung tersebut di antara dua tabung dengan warna standar. Darah ikan dimasukkan ke dalam tabung sahli sebanyak $0,02 \mathrm{~mL}$ dengan pipet sahli. Lalu didiamkan tiga menit. Akuades kemudian ditambahkan dengan pipet tetes sedikit demi sedikit sambil diaduk sampai warnanya tepat sama dengan warna standar. Kadar hemoglobin dinyatakan dalam persen $(\%)$.

\section{Analisis Data}

Data sintasan yang diperoleh dianalisis menggunakan sidik ragam (ANOVA) pada selang kepercayaan $95 \%$ dan data yang berbeda nyata diuji menggunakan uji lanjut Duncan. Data biomassa, NBT assay, kadar hematokrit, hemoglobin, dan total bacterial count dianalisis secara deskriptif.

\section{HASIL DAN BAHASAN}

\section{Aplikasi Kombinasi Probiotik \\ Mikroenkapsulasi dan Tanpa \\ Mikroenkapsulasi Secara In Vivo}

Tingkat sintasan ikan lele pada perlakuan PM dengan penyalut gabungan whey dan maltodekstrin dan PNM menunjukkan adanya perbedaan yang signifikan setelah uji tantang dengan A. hydrophila $\left(10^{7} \mathrm{cfu} / \mathrm{mL}\right)$ dibandingkan kontrol negatif dan kontrol positif $(P<0,05$; Tabel 2). Sedangkan antara perlakuan probiotik mikroenkapsulasi dan tidak dimikroenkapsulasi juga berbeda nyata $(P<0,05$; Tabel 2). Hal ini mengindikasikan bahwa pemberian probiotik mikroenkapsulasi lebih efektif dibandingkan probiotik tanpa dimikroenkapsulasi. Proses mikroenkapsulasi menghasilkan probiotik yang stabil sehingga dapat memperbaiki daya hidupnya selama proses processing, penyimpanan dan di dalam saluran cerna.

Mikroenkapsulasi merupakan teknik pengemasan bahan dalam bentuk partikel mikro dan nano. Mikroenkapsulasi dapat melindungi bahan sensitif dari kelembaban, panas, cahaya atau oksidasi (Jafari et al., 2008). Zubaidah (2014) menyatakan bahwa penentuan bahan penyalut terbaik tidak hanya didasarkan pada uji viabilitas mikrokapsul saja, tetapi juga didasarkan pada tekstur mikrokapsul pada akhir pengamatan. Bahan penyalut maltodekstrin saja tidak mampu mempertahankan tekstur mikrokapsul yang berupa serbuk, berbeda dengan bahan penyalut gabungan antara whey dan maltodekstrin. Menurut Zubaidah (2014), bahan penyalut gabungan whey dan maltodekstrin mampu mempertahankan tekstur mikrokapsul probiotik hingga akhir pengamatan selama 40 hari dan rendemen yang dihasilkan juga lebih tinggi.

Aktivitas produksi oksigen radikal superoksida $\left(\mathrm{O}_{2}^{-}\right)$pada Aktivitas fagositosis dapat dilihat dengan menggunakan pewarnaan NBT. Nilai NBT yang semakin tinggi menunjukkan bahwa produksi radikal oksigen bebas pada Aktivitas respiratory burst semakin besar (Tabel 3). Produksi radikal bebas ini digunakan untuk melawan patogen. Tubuh ikan mempunyai mekanisme membunuh sel-sel fagosit melalui oksigen bebas dalam vakuola lisosom yang mampu meningkatkan permeabilitas sel bakteri patogen sehingga bisa menyebabkan masuknya substansi dan cairan dalam sel bakteri patogen yang kemungkinan bisa menyebabkan plasmolisis. 
Tabel 2. Sintasan ikan lele Clarias gariepinus dengan pemberian probiotik mikroenkapsulasi dan tanpa mikroenkapsulasi dalam pakan sebelum dan sesudah uji tantang dengan A. hydrophila

Table 2. Survival rate of catfish Clarias gariepinus fed with microencapsulated and non-microencapsulated probiotic applications before and after challenge test with $\mathbf{A}$. Hydrophila

\begin{tabular}{lcc}
\hline \multirow{2}{*}{$\begin{array}{c}\text { Perlakuan } \\
\text { Treatments }\end{array}$} & \multicolumn{2}{c}{ Sintasan (Survival rate) (\%) } \\
\cline { 2 - 3 } & $\begin{array}{c}\text { Sebelum uji tantang } \\
\text { Before challenge test }\end{array}$ & $\begin{array}{c}\text { Sesudah uji tantang } \\
\text { After challenge test }\end{array}$ \\
\hline K- & $91.11 \pm 3.845^{\mathrm{a}}$ & $93.33 \pm 3,67^{\mathrm{a}}$ \\
K+ & - & $74.67 \pm 4,37^{\mathrm{b}}$ \\
PM & $95.56 \pm 7.696^{\mathrm{a}}$ & $97.33 \pm 3,85^{\mathrm{c}}$ \\
PNM & $95.56 \pm 3.851^{\mathrm{a}}$ & $89.33 \pm 6,07^{\mathrm{a}}$ \\
\hline
\end{tabular}

Hasil analisis NBT terhadap ikan yang diberi probiotik menunjukkan suatu peningkatan jumlah oksidatif radikal jika dibandingkan dengan kontrol negatif maupun kontrol positif yang diuji tantang. Semakin tinggi nilai NBT maka kemampuan sel fagosit dalam aktivitas respiratory burst semakin tinggi. Hal ini juga menunjukkan bahwa kedua jenis probiotik baik PM maupun PNM bersifat imunostimulan yaitu mampu mengaktivasi neutrofil dan sel-sel fagositik yang lain untuk memproduksi oksigen radikal yang lebih tinggi sehingga dapat memberikan ketahanan terhadap penyakit.

Dosis pemberian probiotik mikroenkapsulasi S. lentus pada pakan sebesar $0,5 \%, 1 \%$ dan $2 \%$ sebelumnya pernah dilaporkan oleh Rahmawati (2015). Pemberian probiotik mikroenkapsulasi S. Ientus tersebut menunjukkan pengaruh yang nyata terhadap laju pertumbuhan dan efisiensi pakan pada ikan nila yang terinfeksi S. agalactiae. Pada Tabel 4 terlihat bahwa penggunaan probiotik mikroenkapsulasi berbagai dosis meningkatkan nilai hematokrit darah sampai hari ke-28. Hematokrit merupakan persentase volume eritrosit atau sel darah merah dalam darah ikan. Eritrosit berperan dalam proses pengangkutan oksigen di dalam tubuh ikan. Perubahan hematokrit dalam darah terjadi karena adanya perubahan proses fisiologis tubuh yang bereaksi terhadap patogen yang masuk.

Probiotik membantu meningkatkan kadar hematokrit pada kondisi ikan terinfeksi yang biasanya akan mengganggu komposisi volume eritrosit darah karena darah dibutuhkan untuk penanggulangan patogen yang masuk.

Hemoglobin merupakan metaloprotein yaitu protein yang mengandung zat besi di dalam sel darah merah yang berfungsi sebagai pengangkut oksigen. Molekul hemoglobin terdiri atas globin, apoprotein, dan empat gugus heme, suatu molekul organik dengan satu atom besi.

Tabel 3. Nilai NBT assay pada ikan lele Clarias gariepinus dengan pemberian probiotik mikroenkapsulasi dan tidak dimikroenkapsulasi dalam pakan sebelum dan sesudah uji tantang dengan $\mathrm{A}$. hydrophila

Table 3. NBT value of catfish Clarias gariepinus with microencapsulated and non-microencapsulated probiotics before and after challenge test with A. hydrophila

\begin{tabular}{lcccc}
\hline \multirow{2}{*}{$\begin{array}{c}\text { Perlakuan } \\
\text { Treatments }\end{array}$} & \multicolumn{4}{c}{ NBT assay } \\
\cline { 2 - 5 } & H-0 & H-7 & H-14 & H-21 \\
\hline K- & 0.043 & 0.041 & 0.042 & 0.042 \\
K+ & 0.045 & 0.051 & 0.067 & 0.056 \\
PM & 0.046 & 0.057 & 0.069 & 0.057 \\
PNM & 0.044 & 0.053 & 0.068 & 0.056 \\
\hline
\end{tabular}


Tabel 4. Nilai hematokrit ikan lele Clarias gariepinus yang diberikan pakan dengan probiotik mikroenkapsulasi pada dosis yang berbeda setelah uji tantang dengan A. hydrophila

Table 4. Haematocrit value of catfish Clarias gariepinus microencapsulated probiotic applications at different dosages after challenge test used $\mathbf{A}$. hydrophila

\begin{tabular}{lccccc}
\hline $\begin{array}{c}\text { Perlakuan } \\
\text { Treatments }\end{array}$ & H-0 & H-7 & H-14 & H-21 & H-28 \\
\hline A & 20.9 & 22.5 & 24 & 31.23 & 32.45 \\
B & 20.9 & 23.52 & 33.27 & 33 & 33.84 \\
C & 20.9 & 20 & 22.43 & 32.5 & 37.69 \\
K+ & 20.9 & 20.57 & 20.11 & 20 & 24.04 \\
K- & 20.9 & 20 & 20 & 22 & 26.8 \\
\hline
\end{tabular}

Tabel 5. Nilai hemoglobin ikan lele Clarias gariepinus dengan pemberian probiotik mikroenkapsulasi pada dosis yang berbeda setelah uji tantang A. hydrophila

Table 5. Hemoglobin value of catfish Clarias gariepinus with microencapsulated probiotic applications at different dosages after challenge test used $\mathbf{A}$. hydrophila

\begin{tabular}{lccccc}
\hline $\begin{array}{l}\text { Perlakuan } \\
\text { Treatments }\end{array}$ & H-0 & H-7 & H-14 & H-21 & H-28 \\
\hline A & 5.7 & 7 & 6.2 & 8.1 & 8.2 \\
B & 5.7 & 7 & 7.9 & 8.47 & 10.2 \\
C & 5.7 & 6 & 7.1 & 8.2 & 11.5 \\
K+ & 5.7 & 6.2 & 5.7 & 6 & 7.25 \\
K- & 5.7 & 6.2 & 7 & 7.2 & 7.1 \\
\hline
\end{tabular}

Dari parameter hematologi, hematocrit, dan hemoglobin, maka pemberian probiotik mikroenkapsulasi berbagai dosis selama 28 hari setelah diuji tantang cenderung semakin meningkat terutama perlakuan C yaitu probiotik mikroenkapsulasi dosis $2 \%$ (Tabel 5). Hal ini menunjukkan penggunaan probiotik akan menjaga homeostasis tubuh di dalam infeksi patogen yang masuk, sehingga ikan tetap hidup dan sehat walaupun terjadi kejadian wabah di sekitarnya. Bakteri probiotik dapat memberikan efek imunostimulan melalui interaksi dengan sel-sel limfoid yang ada di saluran cerna atau disebut sebagai Gut associated Lymphoid Tissue (GALT) sehingga mampu menstimulasi sistem imun ikan (El-Bouhy et al., 2013).

Penggunaan probiotik mikroenkapsulasi juga meningkatkan biomassa ikan uji seiring dengan peningkatan dosis pemberian probiotik (Tabel 6). Hal ini sesuai dengan pernyataan Zubaidah et al. (2015) bahwa semakin tinggi dosis Bacillus sp. yang diberikan maka laju pertumbuhan semakin meningkat. Adanya probiotik membantu memudahkan penyerapan dan pemanfaatan nutrien menjadi lebih efisien sehingga berpengaruh terhadap biomassa ikan.

Pada Tabel 7 disajikan total bakteri pada saluran pencernaan selama masa pemeliharaan 40 hari. Walaupun total bakteri di saluran pencernaan pada seluruh perlakuan probiotik diketahui memiliki jumlah yang lebih tinggi dibandingkan kontrol, perlakuan $\mathrm{C}$ memberikan hasil tertinggi (Tabel 7).

Peningkatan dosis pemberian probiotik mengakibatkan peningkatan total bakteri dan total probiotik pada saluran pencernaan ikan uji. Peningkatan jumlah total bakteri di saluran pencernaan akibat pemberian probiotik Bacillus sp. melalui pakan pada Oreochromis niloticus (Utami et al., 2015) juga pernah dilaporkan sebelumnya. 
Tabel 6. Berat biomasa ikan lele Clarias gariepinus dengan pemberian probiotik mikroenkapsulasi pada dosis yang berbeda setelah 40 hari pemeliharaan

Table 6. Biomass of catfish Clarias gariepinus microencapsulated probiotic application at different dosages after 40 days rearing period

\begin{tabular}{lcc}
\hline $\begin{array}{c}\text { Perlakuan } \\
\text { Treatments }\end{array}$ & $\begin{array}{c}\text { Total } \\
(\mathbf{g})\end{array}$ & $\begin{array}{c}\text { Ratarata } \\
\text { Mean }(\mathbf{g})\end{array}$ \\
\hline A & 833.86 & 277.9533 \\
B & 946.58 & 315.5267 \\
C & 918.88 & 306.2933 \\
K+ & 812.90 & 270.9667 \\
K- & 733.82 & 244.6067 \\
\hline
\end{tabular}

Tabel 7. Total bacterial count (TBC) dan total probiotic count (TPC) B. cereus ND2 dan S. lentus L1K pada saluran pencernaan ikan lele yang diberi probiotik mikroenkapsulasi menggunakan dosis yang berbeda

Table 7. Total bacterial count (TBC) and total probiotic count (TPC) B. cereus ND2 and S. lentus L1K in the digestive tract of catfish fed with different dosages of probiotic microencapsulated feeds

\begin{tabular}{|c|c|c|c|}
\hline \multirow{2}{*}{$\begin{array}{l}\text { Perlakuan } \\
\text { Treatments }\end{array}$} & \multirow{2}{*}{$\begin{array}{c}\text { TBC } \\
\left(\log \text { CFU g } g^{-1}\right)\end{array}$} & \multicolumn{2}{|c|}{ TPC $\left(\log\right.$ CFU g $\left.{ }^{-1}\right)$} \\
\hline & & B. cereus ND2 & S. lentus L1K \\
\hline K & $6.30 \pm 0.150$ & $0.00 \pm 0.000$ & $0.00 \pm 0.000$ \\
\hline$A$ & $6.82 \pm 0.518$ & $3.11 \pm 0.173$ & $3.1 \pm 0.066$ \\
\hline B & $6.85 \pm 0.181$ & $3.86 \pm 0.075$ & $3.59 \pm 0.167$ \\
\hline C & $6.99 \pm 0.834$ & $4.26 \pm 0.086$ & $4.42 \pm 0.182$ \\
\hline
\end{tabular}

\section{KESIMPULAN}

Suplementasi probiotik mikroenkapsulasi dari kombinasi Bacillus cereus ND2 dan Staphylococcus lentus L1K pada pakan dengan dosis $2 \%$ menunjukkan hasil yang lebih baik dengan sintasan $97,33 \%$ dan meningkatkan biomassa dan respons imun (NBT assay, hematokrit, hemoglobin) ikan lele Clarias gariepinus terhadap A. hydrophila.

\section{UCAPAN TERIMA KASIH}

Terima kasih kepada Kepala Balai Balai Penelitian dan Pengembangan Budidaya Air Tawar,E Bogor atas terselenggaranya penelitian ini dan teknisi litkayasa yang membantu secara teknis untuk pengambilan data.

\section{DAFTAR ACUAN}

Anderson, D.P. \& Siwicki, A.K. (1995). Basic hematology and serology for fish health programs. Paper presented in second symposium on diseases in Asian Aquaculture "Aquatic Animal Health and The Environment". Phuket Thailand, 25-29 th $^{\text {October }} 1993$. $17 \mathrm{pp}$.
Cruz, P.M., Ibanez, A.I., Hermosillo, A.M., \& Saad, H.C.R. (2012). Use of probiotics in aquaculture. [review article]. International Scholarly research Network Microbiology 2012:13. Doi:10.5402/ 2012/916845.

El-Bouhy, Z.M., El-Nobi, G.A., Hassanin, M.E., \& ElHady, M.A. (2013). Effects of dietary application of two antagonistic gut-isolated Bacillus species on the immune response of Oreochromis niloticus to Aeromonas hydrophila Infection. Zag. Vet. J., 41(2), 31-39.

Hasibuan. (2013). Aplikasi probiotik amilolitik dan proteolitik melalui pakan untuk pengendalian Streptococcosis pada ikan nila, Oreochromis niloticus. Institut Pertanian Bogor. $54 \mathrm{hlm}$.

Iribarren, D., Daga, P., Moreirn, M.T., \& Feijoo, G. (2012). Potential environmental effects of probiotics used in aquacultyure. Aquaculture International, 20, 779-789.

Jafari, S.M., Assadpoor, E., He, Y., \& Bhandari, B. (2008). Encapsulation efficiency of food flavours and oils during spray drying, Drying Technology, 26(7), 816-835. 
Jackson, L.S. \& Lee, K. (1991). Microencapsulation and the food industry. Lebensmittel-W issenschaft Technologie, $143 \mathrm{pp}$.

Krasaekoopt, W., Bhandari, B., \& Deeth, H. (2003). Evaluation of encapsulation tehniques of probiotics for yoghurt. International Dairy Journal, 13, 3-13.

Munaeni, W., Yuhana, M., \& Widanarni. (2014). Effect of micro-microencapsulated synbiotic at different frequencies for luminous vibriosis control in white shrimp (Litopenaeus vannamei). Jurnal Mikrobiologi Indonesia, 8(2), 73-80.

Nimrat, S., Suksawat, S., Boonthai, T., \& Vuthiphandchai, V. (2012). Potential Bacillus probiotics enhance bacterial numbers, water quality and growth during early development of white shrimp (Litopenaeus vannamei). Vet. Microbiol., 159, 443-450.

Rahmawati, F.F. (2015). Suplementasi mikrokapsul probiotik melalui pakan sebagai pencegah infeksi Streptococcosis pada ikan nila (Oreochromis niloticus). Tesis. Institut Pertanian Bogor.

Secombes, C.J. (1990). Isolation of salmonid macrophages and analysis of their killing activity. In Stolen, J.S., Fletcher, T.C., Anderson, D.F., Roberson, B.S., von Muisvinkel, W.B. (Eds.). Tehniques in fish immunology Vol 1. SOS Publications. Fair Haven, p. 137-155.

Sekar, S., Surianarayanan, M., Perinkulam, R.D., Bhusvanesh, K.S., Phani, K., \& Asit, B.M. (2012). The metabolic advantage of choline lactate in growth media: an experimental analysis with Staphylococcus lentus. App. Bioxhem. Biotech., 169, 380-392.
Seveline. (2005). Pengembangan produk probiotik dari isolat klinis bakteri asam laktat dengan menggunakan teknik pengeringan semprot dan pengeringan beku. Tesis. Institut Pertanian Bogor. Bogor, $78 \mathrm{hlm}$.

Thomas, L.W. \& Chhorn, L. (2011). Use of probiotics in diets of tilapia. Journal of Aqua Res. Development, 31, 2-8.

Utami, D.A.S., Widanarni, \& Suprayudi, M.A. (2015). Administration of micromicroencapsulated probiotic at different doses to control Streptococcosis in tilapia (Oreochromis niloticus). Jurnal Mikrobiologi Indonesia, 9(1), 17-24.

Victor, R.P. \& Heldman, D.R. (2001). Introduction to food engineering. 3rd ed. London: Academics Press. 120 pp.

Wedemeyer, G.A. \& Yasutake, W.T. (1977). Clinical methods for the assessment of the effect on environmental stress on fish health. Technical papers of the US Fish and Wildlife Service. US depart. of the Interior. J. Fish and Wildlife Service, 89, 1-17.

Weinbreck, F., Bodnar, I., \& Marco, M.L. (2010). Can encapsulation lengthen the shelf-life of probiotic bacteria in dry products?. International Journal of Food Microbiology, 136, 364-367.

Zubaidah, A. (2014). Pemberian mikrokapsul sinbiotik dengan dosis berbeda melalui pakan untuk pencegahan vibriosis pada udang vaname (Litopenaeus vannamei). Tesis. Institut Pertanian Bogor. Bogor, $67 \mathrm{hlm}$.

Zubaidah, A., Yuhana, M., \& Widanarni. (2015). Encapsulated synbiotic dietary supplementation at different dosages to prevent vibriosis in white shrimp, Litopenaeus vannamei. Jurnal Hayati Bioscience, 22, 163-168. Doi:10.1016/ j.hjb.2015.10.007. 